\title{
Purification and some Properties of Glutamine Synthetase from the Nitrogen-fixing Cyanobacteria Anabaena cylindrica and a Nostoc sp.
}

\author{
By MARIA JOSE A. M. SAMPAIO, PETER ROWELL \\ AND WILLIAM D. P. STEWART \\ Department of Biological Sciences, University of Dundee, Dundee DD1 4HN, Scotland
}

(Received 4 September 1978)

Glutamine synthetase has been purified to homogeneity from two $\mathrm{N}_{2}$-fixing cyanobacteria, Anabaena cylindrica and a species of Nostoc (the phycobiont of Peltigera canina). The activities of the $A$. cylindrica enzyme in the biosynthetic and transferase assays were, respectively, 9.4 and $32 \mu \mathrm{mol}$ product formed $\min ^{-1}$ (mg protein) $)^{-1}$; the corresponding values for the Nostoc sp. enzyme were 6.5 and 20. Stabilization of the enzyme required $\mathrm{Mg}^{2+}$, glutamate, EDTA and a thiol reagent to be present during purification.

The molecular weight of the $A$. cylindrica enzyme was 591000 as estimated by sedimentation analysis, 660000 by gel filtration and 565000 by polyacrylamide gel electrophoresis; the Nostoc sp. enzyme gave values of 630000 by gel filtration and 575000 by electrophoresis. The molecular weights of the sub-units of each enzyme were approximately 49000 to 50000 . Electron microscopy revealed that each molecule was composed of 12 sub-units arranged in two superimposed hexagonal rings. The maximum diameter of the rings was $13.6 \mathrm{~nm}$ and the distance between the centres of adjacent sub-units was $4.9 \mathrm{~nm}$.

When dialysed in the absence of stabilizing ligands the $A$. cylindrica enzyme lost activity and the protein band characteristic of the native enzyme was replaced by three bands with approximate molecular weights of 510000,310000 and 130000 . These sub-species reassociated and activity was restored by adding 2-mercaptoethanol and substrates. A similar reversible deactivation has been observed with glutamine synthetase from photosynthetic eukaryotes and yeast but no similar data have been reported for a $\mathrm{N}_{2}$-fixing prokaryote.

\section{INTRODUCTION}

Previously, we have provided evidence based on enzyme studies (Dharmawardene et al., 1973; Rowell et al., 1977), the use of analogues (Stewart \& Rowell, 1975; Ladha et al., 1978 ) and ${ }^{15} \mathrm{~N}$ tracer studies (Stewart et al., 1975) that glutamine synthetase is a major enzyme involved in $\mathrm{NH}_{4}{ }^{+}$assimilation in $\mathrm{N}_{2}$-fixing cyanobacteria. This conclusion is also supported by other work (Wolk et al., 1976; Meeks et al., 1977; Ownby, 1977; Thomas et al., 1977) and there is now substantial evidence that the glutamine synthetase/glutamate synthase pathway (see, for example, Brown et al., 1974) is the primary route of $\mathrm{NH}_{4}{ }^{+}$ assimilation in $\mathrm{N}_{2}$-fixing cyanobacteria. This also appears to be the case in $\mathrm{N}_{2}$-fixing heterotrophic bacteria (Nagatani et al., 1971) and in photosynthetic bacteria (Brown \& Herbert, $1977 a, b$; Johansson \& Gest, 1977).

The properties and regulation of the purified glutamine synthetase of $\mathrm{N}_{2}$-fixing cyanobacteria have not so far been reported in detail, but no evidence of regulation by an adenylylation-deadenylylation mechanism was obtained from studies using crude extracts and partially purified preparations (Dharmawardene et al., 1973; Rowell et al., 1977; Sawhney 
\& Nicholas, 1978). However, such a regulatory mechanism has been noted in most other $\mathrm{N}_{2}$-fixing prokaryotes so far studied, including various free-living heterotrophic bacteria (Tronick et al., 1973), Rhizobium (Rao et al., 1978) and photosynthetic bacteria (Johansson $\&$ Gest, 1977). As a prerequisite to detailed studies on the regulation of cyanobacterial glutamine synthetase, we report here a method for the purification of the enzyme from Anabaena cylindrica, and from a Nostoc species isolated from the lichen Peltigera canina, and present information on the structural characteristics of the purified enzymes as well as data on certain aspects of the regulatory properties of cyanobacterial glutamine synthetase. The data complement and extend those obtained by Stacey et al. (1977), who recently purified glutamine synthetase from a marine cyanobacterium, Anabaena strain CA.

\section{METHODS}

Organisms. Anabaena cylindrica Lemm. (CU 1403/2a) and the isolated Nostoc sp., phycobiont of the lichen Peltigera canina (obtained originally from Dr J. W. Millbank, Imperial College, London), were used in axenic culture.

Culturing of the cyanobacteria. Anabaena cylindrica and Nostoc sp. were grown in BG-11 medium (Stanier et al., 1971) and in the medium of Allen \& Arnon (1955), respectively, in continuous culture at $30^{\circ} \mathrm{C}$ and 3000 lux with $\mathrm{N}_{2}$ as the nitrogen source. Cyanobacteria used for purification of glutamine synthetase were grown in batch culture (50 to $100 \mathrm{l})$ at $30^{\circ} \mathrm{C}$ and $3000 \mathrm{lux}$ and harvested in the late-exponential growth phase.

Enzyme extraction and purification. Cultures were harvested by centrifugation, washed twice in $50 \mathrm{~mm}$ Tris/ $\mathrm{HCl}$ buffer, $\mathrm{pH} 7 \cdot 5$ (buffer A) and resuspended in buffer B (buffer A supplemented with $5 \mathrm{~mm}-\mathrm{MgCl}_{2}$, 10 mm-sodium glutamate, $5 \mathrm{~mm}$-2-mercaptoethanol and 1 mM-EDTA). In all subsequent steps, buffer $B$ was used unless otherwise stated. Cyanobacteria were disrupted by passage through a French pressure cell at $110 \mathrm{MPa}$. Debris was removed by centrifugation at $35000 \mathrm{~g}$ for $30 \mathrm{~min}$, the supernatant was treated with $\left(\mathrm{NH}_{4}\right)_{2} \mathrm{SO}_{4}$ to $40 \%$ saturation for $30 \mathrm{~min}$, and then centrifuged at $35000 \mathrm{~g}$ for $30 \mathrm{~min}$. The resulting supernatant was treated with $\left(\mathrm{NH}_{4}\right)_{2} \mathrm{SO}_{4}$ to $70 \%$ saturation and, after $30 \mathrm{~min}$, re-centrifuged at $35000 \mathrm{~g}$ for $30 \mathrm{~min}$. The pellet was suspended in a minimal volume of buffer $\mathrm{B}$ and dialysed to remove $\left(\mathrm{NH}_{4}\right)_{2} \mathrm{SO}_{4}$. The resulting solution was chromatographed on DEAE-cellulose $(30 \times 3.2 \mathrm{~cm}$ column) and eluted with a gradient of 0 to $0.5 \mathrm{M}-\mathrm{KCl}$ in buffer B. Active fractions were bulked and concentrated to less than $3.0 \mathrm{ml}$ by vacuum dialysis. The concentrated enzyme was then chromatographed on a $100 \times 2.5 \mathrm{~cm}$ column of Sepharose 6B. Active fractions were bulked and concentrated by vacuum dialysis. Such preparations were occasionally homogeneous but it was usually necessary to further purify the enzyme by chromatography on a $10 \times 1 \mathrm{~cm}$ column of aminohexane-Sepharose $4 \mathrm{~B}$, eluting the enzyme with a gradient of 0 to $0.8 \mathrm{M}-$ sodium glutamate in buffer B. Active fractions were again concentrated by vacuum dialysis. All operations were carried out at $4{ }^{\circ} \mathrm{C}$.

Glutamine synthetase assays (EC 6.3.1.2). (i) Biosynthetic activity, $\mathrm{Mg}^{2+}$-dependent. A modification of the method of Kingdon et al. (1968) was used in which the production of ADP was coupled to the oxidation of NADH. This assay, which allows continuous monitoring of activity, avoids problems which might arise from the more commonly used $\mathbf{P}_{\mathbf{i}}$ release assay for an enzyme which shows slow, time-dependent, changes in activity. The reaction mixture contained, in addition to enzyme, in $3 \mathrm{ml}: 150 \mu \mathrm{mol}$ Tris/ $\mathrm{HCl}$ buffer, $\mathrm{pH} 7.5 ; 3.0 \mu \mathrm{mol}$ ATP; $200 \mu \mathrm{mol} \mathrm{NH} \mathrm{NCl}_{4} ; 60 \mu \mathrm{mol}$ sodium glutamate; $150 \mu \mathrm{mol} \mathrm{MgCl}_{2} ; 150 \mu \mathrm{mol}$ $\mathrm{KCl} ; 0.45 \mu \mathrm{mol} \mathrm{NADH} ; 0.5 \mu \mathrm{mol}$ phosphoenolpyruvate; 20 units lactate dehydrogenase; (EC 1.1.1.27); 8 units pyruvate kinase (EC 2.7.1.40). Unless otherwise stated, the reaction was initiated by adding glutamate and the rate of oxidation of $\mathrm{NADH}$ at $30^{\circ} \mathrm{C}$ was measured at $340 \mathrm{~nm}$. None of the reagents used affected the activity of the coupling enzymes.

(ii) $\gamma$-Glutamyl transferase activity, $\mathrm{Mn}^{2+}$-dependent. This was estimated by a modification of the method described by Pamiljans et al. (1962). The reaction mixture contained, in addition to enzyme, in $1 \mathrm{ml}: 40 \mathrm{mM}$ -

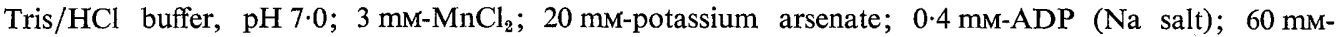
hydroxylamine; $30 \mathrm{~mm}$-glutamine. Incubations were at $30^{\circ} \mathrm{C}$ for $10 \mathrm{~min}$ in the dark.

Protein determinations. The method of Lowry et al. (1951) was used, with bovine serum albumin as the standard. For purified enzyme preparations the spectrophotometric method of Layne (1957) was occasionally used (see Results).

Gel electrophoresis. Polyacrylamide gel electrophoresis was carried out according to Davis (1964) and, for molecular weight estimations, according to Hedrick \& Smith (1968), on 5, 7.5, 11 and $15 \%$ (w/v) gel columns using Tris/glycine buffer, $\mathrm{pH} 8 \cdot 8$, and a current of $3 \mathrm{~mA}$ per gel tube. The molecular weight 
standards were fatty acid synthetase (520000), $\beta$-galactosidase (480000), ferritin (450000), bovine serum albumin dimer (136000) and monomer (68000). Gels were stained for protein with $0 \cdot 2 \%(\mathrm{w} / \mathrm{v})$ Coomassie Brilliant Blue in acetic acid/methanol/water $(10: 45: 45$, by vol.) for 5 to $15 \mathrm{~h}$ at room temperature, destained with acetic acid/methanol/water $(10: 25: 65$, by vol.) and scanned at $600 \mathrm{~nm}$ using a Gilford $2410-\mathrm{S}$ gel scanner (Gilford Instruments, Teddington, Middx).

Polyacrylamide gel electrophoresis in the presence of sodium dodecyl sulphate (SDS) was carried out according to Weber \& Osborn (1969) using 7.5\% (w/v) gels and a current of $6.5 \mathrm{~mA}$ per gel tube. The molecular weight standards were bovine serum albumin dimer (136000) and monomer (68000), catalase (58000), $\gamma$-globulin-H-chain (50000), aldolase (40000), yeast alcohol dehydrogenase (37000), chymotrypsinogen (25700) and $\gamma$-globulin-L-chain (23500). Proteins in $1 \%(\mathrm{w} / \mathrm{v})$ SDS plus $1 \%(\mathrm{w} / \mathrm{v}) 2$-mercapto-

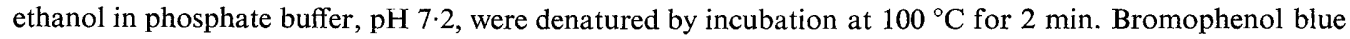
was used as the tracking dye and gels were stained as above.

Electron microscopy of purified glutamine synthetase. A carbon-coated grid (3.05 mm diam.) was touched on to a drop of purified glutamine synthetase solution for $30 \mathrm{~s}$. The grid was then transferred to a drop of $2.6 \%(\mathrm{w} / \mathrm{v})$ phosphotungstic acid for $30 \mathrm{~s}$, dried and examined using an AEI model 801 electron microscope at $60 \mathrm{kV}$ and a magnification of 63000 .

Determination of molecular weight. Purified glutamine synthetase at an initial concentration of $0 \cdot 3 \mathrm{mg} \mathrm{ml}^{-1}$ in buffer $\mathrm{B}$ was centrifuged to equilibrium at $10{ }^{\circ} \mathrm{C}$ in a Beckman model $\mathrm{E}$ analytical ultracentrifuge (Yphantis, 1964). Short liquid columns $(3 \mathrm{~mm})$ in a cell with a double-sector centre-piece were used. The density of buffer B was $1.004 \mathrm{~g} \mathrm{ml}^{-1}$. The partial specific volume $(v)$ of $A$. cylindrica glutamine synthetase was calculated from its amino acid composition according to Schachman (1957). The amino acid composition of the enzyme was determined after hydrolysis in $6 \mathrm{M}-\mathrm{HCl}$ for $24 \mathrm{~h}$ and $60 \mathrm{~h}$ at $110^{\circ} \mathrm{C}$ in vacuo. Analyses were carried out according to Spackman et al. (1958) using a BioCal BC-100 amino acid analyser. Cysteine was determined after oxidation with performic acid (Moore, 1963) and tryptophan by the method of Spies \& Chambers (1949).

The molecular weight of glutamine synthetase was also estimated by gel filtration on a $110 \times 0.9 \mathrm{~cm}$ column of Sepharose 4B (void vol. $24 \mathrm{ml}$ ). The molecular weight standards were phosphorylase kinase (1300000), fatty acid synthetase (520000) and $\beta$-galactosidase (480000).

Chemicals. NADH, phosphoenolpyruvate, lactate dehydrogenase, pyruvate kinase, alcohol dehydrogenase and catalase were from Boehringer. 2-Mercaptoethanol, $\beta$-galactosidase, bovine serum albumin, aminohexane-Sepharose 4B, urease, blue dextran, ADP, ATP, hydroxylamine, L-glutamic acid, Sepharose 4B and Sepharose 6B were from Sigma. Phosphotungstic acid was from TAAB Laboratories, Reading, Berks. All other chemicals were from $\mathrm{BDH}$.

\section{RESULTS}

\section{Purification of glutamine synthetase}

The activities and yields obtained at various stages of purification of the glutamine synthetase from $\mathrm{N}_{2}$-fixing $A$. cylindrica are presented in Table 1 . The specific activities of the purified enzyme were 9.36 and $32.00 \mu$ mol product formed $\min ^{-1}$ (mg protein) ${ }^{-1}$ in the biosynthetic and transferase assays, respectively. The corresponding values for the purified Nostoc sp. enzyme were 6.53 and $20.00 \mu \mathrm{mol} \mathrm{min}-1$ (mg protein) ${ }^{-1}$. These values, based on protein concentrations determined by the method of Lowry et al. (1951), are somewhat higher than those obtained using protein concentrations estimated from the absorbance at $280 \mathrm{~nm}$ (Layne, 1957). The latter values are included in Table 1 to allow direct comparison with the results of Stacey et al. (1977) who purified glutamine synthetase from Anabaena CA. The purified enzymes showed higher biosynthetic activities than the Anabaena CA enzyme, the purifications obtained being 213-fold and 65-fold for the $A$. cylindrica and Nostoc sp. enzymes, respectively. Stabilization of the enzyme was achieved by using buffer B (containing $\mathrm{Mg}^{2+}$, glutamate, EDTA and 2-mercaptoethanol) at all stages of purification; the enzyme could then be stored at $4{ }^{\circ} \mathrm{C}$ for several days with little loss of activity. Biosynthetic activity was lost when $\mathrm{Mg}^{2+}$ was replaced by $\mathrm{Mn}^{2+}$. A slight increase in total activity during $\left(\mathrm{NH}_{4}\right)_{2} \mathrm{SO}_{4}$ fractionation was consistently observed and has previously been noted (Stacey et al., 1977). The enzyme purified from each cyanobacterium showed only a single protein band on electrophoresis using 7.5 and $5 \%$ polyacrylamide gels (Fig. 1 $a, b$; Fig. $2 a, b$ ). 
Table 1. Purification and activity of glutamine synthetase from $A$. cylindrica

Activities were measured by the biosynthetic assay and are expressed as $\mu$ mol product formed $\min ^{-1}$. Specific activities [ $\mu \mathrm{mol}$ product formed $\min ^{-1}(\mathrm{mg} \text { protein })^{-1}$ ] are based on protein determinations by the method of Lowry et al. (1951), except those shown in parentheses which are based on protein determinations by the method of Layne (1957) (see text).

Sample

Crude extract

50 to $70 \%\left(\mathrm{NH}_{4}\right)_{2} \mathrm{SO}_{4}$ fraction

DEAE-cellulose eluate

Sepharose 6B eluate

Aminohexane-Sepharose 4B eluate

$\begin{gathered}\text { Total protein } \\ (\mathrm{mg})\end{gathered}$
4200
1560
140
$9 \cdot 1(17 \cdot 2)$
$4 \cdot 0(7 \cdot 5)$

Yield

$(\%)$

100

115

67

32

20

* The transferase activity of this preparation was $32 \cdot 0 \mu \mathrm{mol}$ product formed $\min ^{-1}$ (mg protein) ${ }^{-1}$.

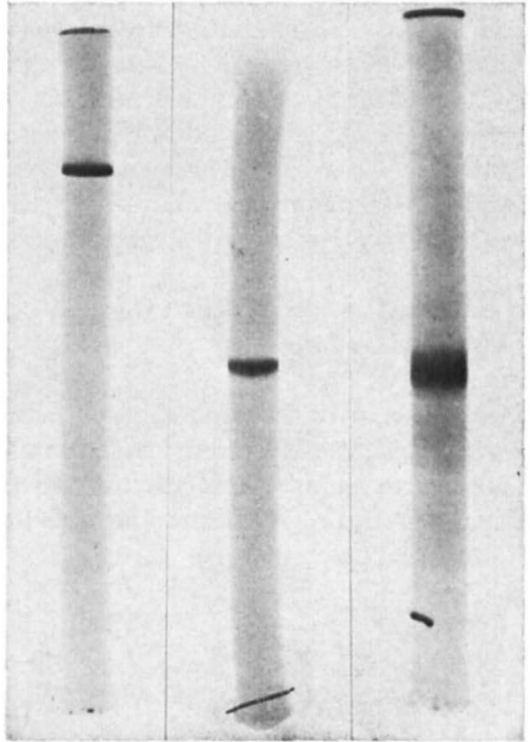

(a) (b) (c)

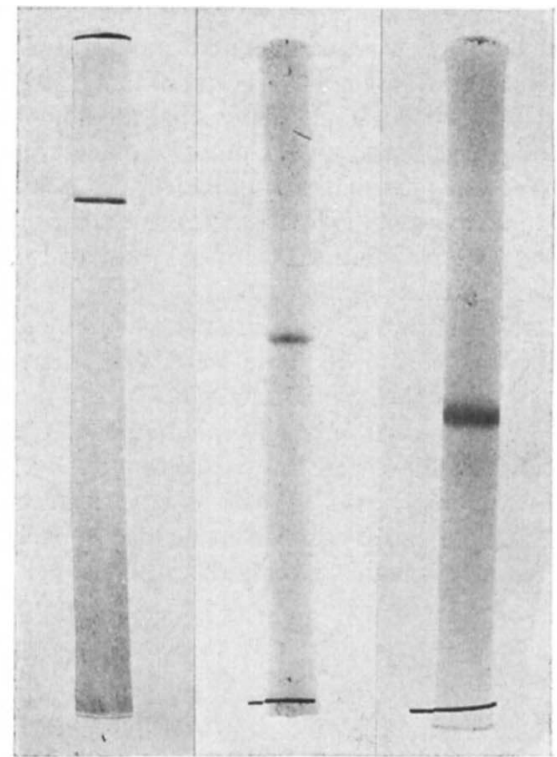

(a) (b) (c)

Fig. 1

Fig. 1. Polyacrylamide gel electrophoresis of purified glutamine synthetase from $A$. cylindrica: (a) $30 \mu \mathrm{g}$ protein on a $7.5 \%$ gel; (b) $30 \mu \mathrm{g}$ protein on a $5 \%$ gel; (c) $30 \mu \mathrm{g}$ protein on a sodium dodecyl sulphate gel. The origin is at the upper end of each gel.

Fig. 2. Polyacrylamide gel electrophoresis of purified glutamine synthetase from Nostoc sp.: (a) $10 \mu \mathrm{g}$ protein on a $7.5 \%$ gel; (b) $10 \mu \mathrm{g}$ protein on a $5 \%$ gel; (c) $20 \mu \mathrm{g}$ protein on a sodium dodecyl sulphate gel. The origin is at the upper end of each gel.

\section{Molecular weight}

From the high-speed equilibrium analysis of the $A$. cylindrica enzyme (Fig. 3 ) and its partial specific volume, calculated from the amino acid composition to be $0.726 \mathrm{ml} \mathrm{g}^{-1}$ (Table 2), the molecular weight of the enzyme was calculated to be 591000 . Molecular weight values based on elution patterns of both enzymes from Sepharose 4B, relative to the elution of proteins of known molecular weight, were approximately 660000 and 630000 for the $A$. cylindrica and Nostoc sp. enzymes, respectively.

The molecular weight of the sub-units of glutamine synthetase from both organisms was estimated by polyacrylamide gel electrophoresis in the presence of sodium dodecyl sulphate. A single band only was detected with each enzyme (Fig. 1c; Fig. 2c). By com- 


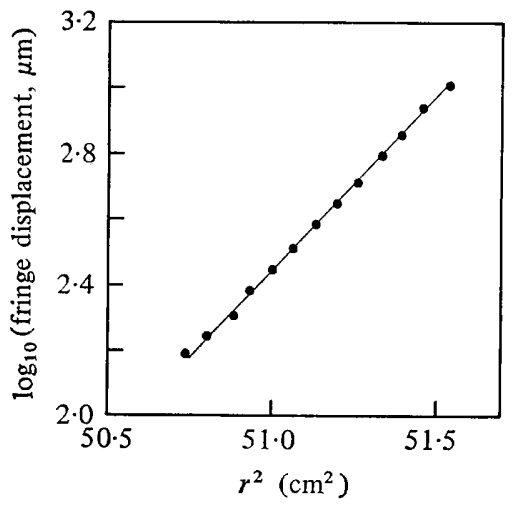

Fig. 3. High-speed sedimentation equilibrium centrifugation of $A$. cylindrica glutamine synthetase in buffer $B$. The plot of $\log _{10}$ (fringe displacement) against the square of the distance from the centre of rotation was obtained from interference patterns recorded after $18 \mathrm{~h}$ at $8000 \mathrm{rev} . \mathrm{min}^{-1}$.

Table 2. Amino acid composition of purified glutamine synthetase from A. cylindrica The values, except for half-cystine and tryptophan, were calculated from the amino acid compositions measured after $24 \mathrm{~h}$ and $60 \mathrm{~h}$ hydrolysis. Half-cystine was determined as cysteic acid after performic acid oxidation (Moore, 1963). Tryptophan was determined by the method of Spies \& Chambers (1949).

Amino acid residue
Aspartic acid
Threonine
Serine
Glutamic acid
Proline
Glycine
Alanine
Valine
Half-cystine
Methionine
Isoleucine
Leucine
Tyrosine
Phenylalanine
Tryptophan
Lysine
Histidine
Arginine
Total

Residues per minimum mol. wt of 49000

$\begin{array}{cc}\text { Calculated } & \text { Nearest integer } \\ 50 \cdot 8 & 51 \\ 25 \cdot 7 & 26 \\ 24 \cdot 7 & 25 \\ 46 \cdot 3 & 46 \\ 26 \cdot 9 & 27 \\ 39 \cdot 1 & 39 \\ 28 \cdot 4 & 28 \\ 14 \cdot 7 & 15 \\ 10 \cdot 4 & 10 \\ 13 \cdot 6 & 14 \\ 28 \cdot 2 & 28 \\ 29 \cdot 7 & 30 \\ 18 \cdot 1 & 18 \\ 27 \cdot 0 & 27 \\ 2 \cdot 3 & 2 \\ 24 \cdot 0 & 24 \\ 7 \cdot 6 & 8 \\ 17 \cdot 3 & 17 \\ - & 435\end{array}$

parison with the electrophoretic mobility of proteins of known molecular weight, the approximate molecular weight of the sub-units of each enzyme was estimated to be 49000 to 50000 .

\section{Electron microscopic examination of glutamine synthetase}

Electron microscopic examination of the purified enzymes from $A$. cylindrica and Nostoc sp. revealed that each molecule had 12 sub-units arranged symmetrically in two hexagonal layers (Fig. 4). Most of the molecules appeared face-on as hexagonal rings while molecules resting on an edge showed a tetrahedral arrangement. With the $A$. cylindrica enzyme, especially after dialysis against buffer A (Fig. 4a), many of the molecules appeared as broken rings; this was not the case with the Nostoc sp. enzyme. The dimensions of the Nostoc sp. enzyme were obtained from the superimposed images of two molecules (Fig. $4 b, c)$, the maximum diameter of the hexagonal ring being approximately $13.6 \mathrm{~nm}$. The 

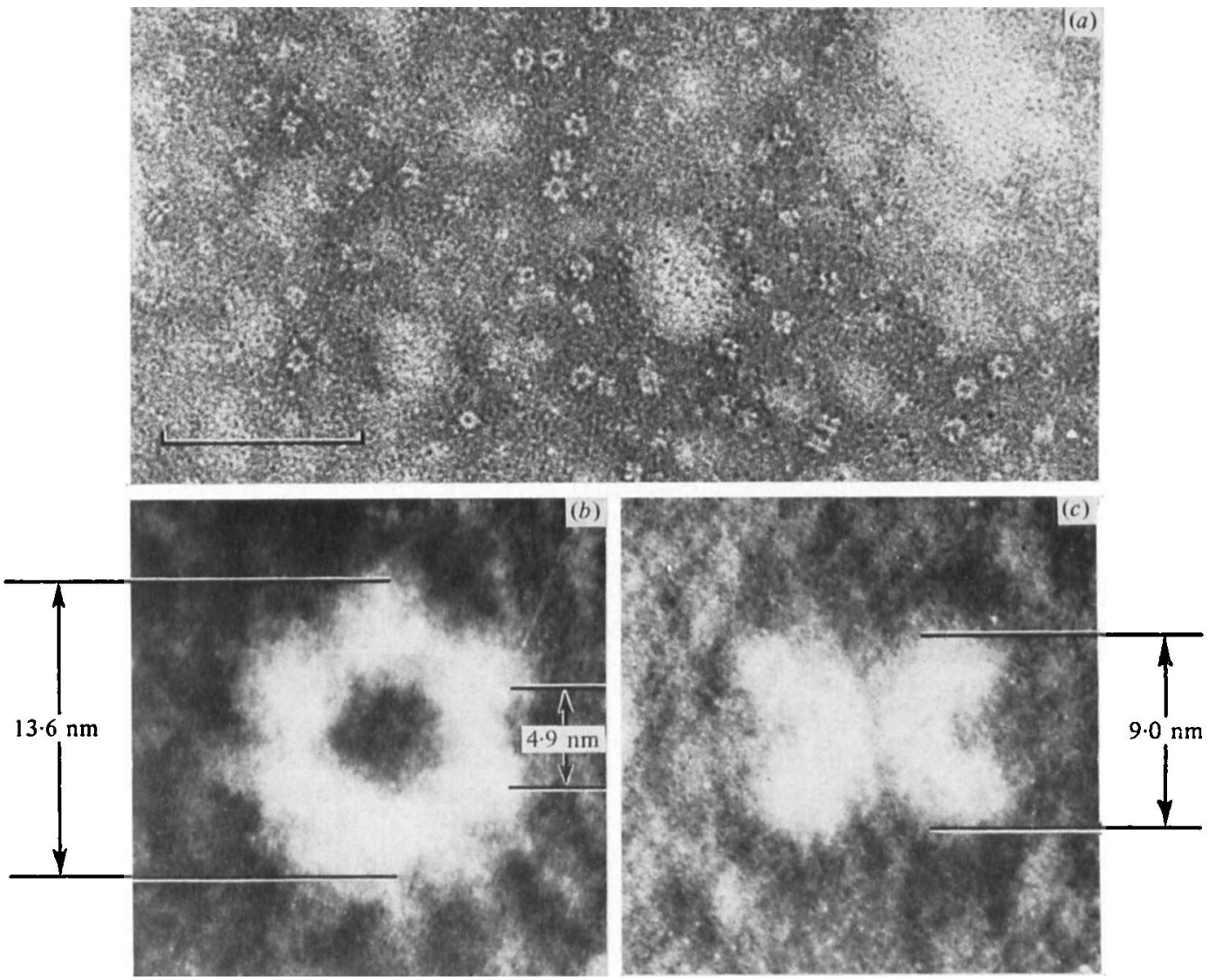

Fig. 4. Electron micrographs of preparations of purified glutamine synthetase from $A$. cylindrica and Nostoc sp.: ( $a$ ) negatively stained preparation of the $A$. cylindrica enzyme (bar marker represents $100 \mathrm{~nm}) ;(b, c)$ the molecular organization of the Nostoc sp. enzyme as seen face-on $(b)$ and end-on (c) when negatives of electron micrographs of two separate negatively stained molecules were superimposed and then printed. Prior to electron microscopy the purified enzyme was dialysed against buffer $\mathrm{A}$, rather than buffer $\mathrm{B}$, because the former gave a clearer background under the electron microscope.

width of each sub-unit and the distance between the centres of adjacent sub-units were approximately $4.9 \mathrm{~nm}$. There were no apparent differences between the $A$. cylindrica and Nostoc sp. enzymes with respect to sub-unit arrangement and dimensions of the molecule.

Reversible deactivation of the purified glutamine synthetase from A. cylindrica

An active homogeneous preparation was invariably obtained when glutamine synthetase was purified from $A$. cylindrica in buffer B (see above). However, enzyme preparations of low activity which showed three bands on electrophoresis (Fig. $5 a$ ) and which could be partially reactivated were obtained in two ways. First, when buffer A was substituted for buffer B during purification, little enzyme activity was obtained but activity could subsequently be increased up to sixfold by adding 2-mercaptoethanol or dithiothreitol together with substrates during the biosynthetic assay. The rate of activation increased with increasing concentration of 2-mercaptoethanol (Fig. 6). Activity was similarly stimulated when such preparations were dialysed against buffer B prior to assay. Stimulation of activity in both cases was accompanied by a complete, or almost complete, disappearance of the three bands (Fig. $5 a$ ) and the appearance of a new band of slightly lower electrophoretic mobility (Fig. $5 b$ ). This latter band had the same electrophoretic mobility as the native enyzme 

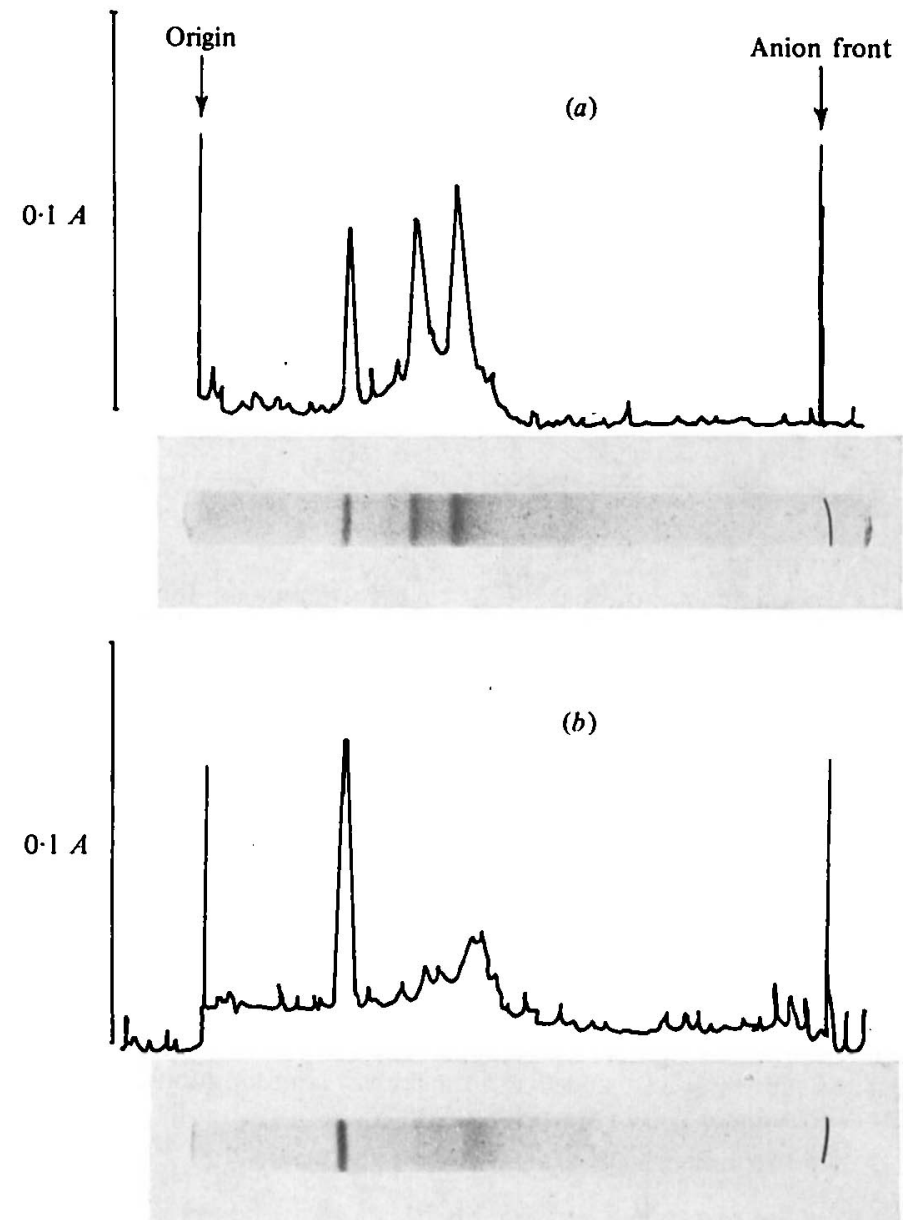

Fig. 5. Effect of treatment with 2-mercaptoethanol and substrates on the electrophoretic mobility of glutamine synthetase purified from $A$. cylindrica: (a) enzyme purified using Tris/HCl buffer, $\mathrm{pH} 7 \cdot 5$, in the absence of stabilizing ligands; $(b)$ enzyme purified as above and then dialysed against $50 \mathrm{~mm}$-Tris $/ \mathrm{HCl}$, pH 7.5, containing $20 \mathrm{~mm}$-sodium glutamate, $1 \mathrm{~mm}-\mathrm{ATP}$ and $40 \mathrm{~mm}$ 2-mercaptoethanol. Each gel was loaded with $20 \mu \mathrm{g}$ protein.

(Fig. $1 a$ ) which, when estimated by electrophoresis on gels using several different polyacrylamide concentrations (Hedrick \& Smith, 1968), had a molecular weight of 565000 . (The corresponding value for the Nostoc sp. enzyme was 575000.) The approximate molecular weights of the other three bands (Fig. $5 a$ ) estimated by this method were, in order of increasing electrophoretic mobility, 510000, 310000 and 130000. The latter two species might represent a half molecule, and a dimer or trimer, respectively. The 510000 molecular weight species might represent a conformer of the native enzyme or, less likely, a molecule which has lost one or two sub-units.

Alternatively, when the fully active enzyme was dialysed for 6 to $8 \mathrm{~h}$ against buffer A and biosynthetic activity and the electrophoretic pattern of the enzyme on gels were then determined, enzyme activity was decreased by $79 \%$ (Table 3 ) and this was again accompanied by the appearance on gels of the three bands noted above. Such deactivated preparations could be reactivated to a maximum of $59 \%$ of the activity of the fully active enzyme by adding both 2-mercaptoethanol and substrates of the biosynthetic assay. Neither 2-mercaptoethanol nor substrates alone caused reactivation. Indeed, the addition of 2-mercaptoethanol alone caused a further loss of activity and a loss of the capacity for 

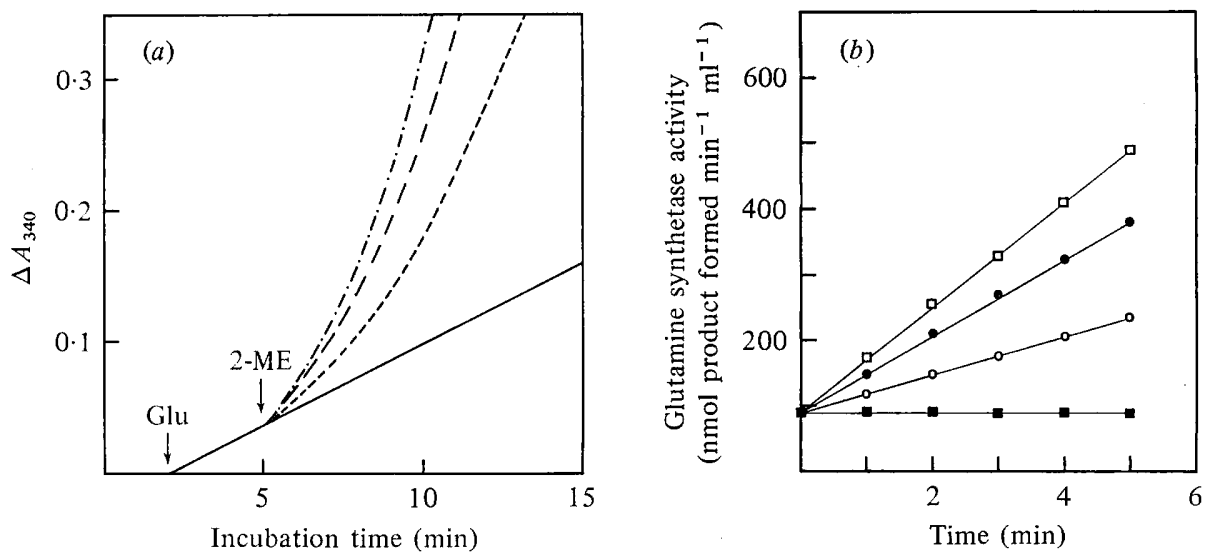

Fig. 6. Effect of various concentrations of 2-mercaptoethanol on the biosynthetic activity of purified glutamine synthetase from $\boldsymbol{A}$. cylindrica. The enzyme was purified using buffer A. (a) Sodium glutamate, to start the reaction, and 2-mercaptoethanol (2-ME) were added at the times arrowed. The final concentrations of 2-mercaptoethanol were $80 \mathrm{~mm}(-\cdot-\cdot), 40 \mathrm{~mm}(-\rightarrow)$ and $20 \mathrm{~mm}$ (------); no 2-mercaptoethanol (-). (b) Effect of period of incubation with substrates and 2-mercaptoethanol $(20 \mathrm{~mm}, \bigcirc ; 40 \mathrm{~mm}, \odot ; 80 \mathrm{~mm}, \square)$ on the biosynthetic activity of the A. cylindrica enzyme. The control (四) did not contain 2-mercaptoethanol.

\section{Table 3. Effects of 2-mercaptoethanol and EDTA on the biosynthetic activity of purified glutamine synthetase from A. cylindrica}

The purified glutamine synthetase was untreated (1) or dialysed (2 to 6) against $50 \mathrm{~mm}-\mathrm{Tris} / \mathrm{HCl}$, $\mathrm{pH} 7 \cdot 5$, for $12 \mathrm{~h}$, and the biosynthetic activity was then determined under the conditions indicated. The reactions were initiated by adding glutamate. Preincubations (before addition of glutamate) were carried out at $30^{\circ} \mathrm{C}$ for $10 \mathrm{~min}$. 2-Mercaptoethanol was added to a concentration of $40 \mathrm{~mm}$, EDTA to $8 \mathrm{~mm}$ and substrates were added at normal assay concentrations. Activities are expressed as $\mu \mathrm{mol}$ product formed $\mathrm{min}^{-1}(\mathrm{ml} \text { enzyme })^{-1}$.

\section{Treatment}

1. Undialysed enzyme (no 2-mercaptoethanol)

2. Dialysed enzyme (no 2-mercaptoethanol)

3. 2-Mercaptoethanol added after substrates and glutamate

4. Incubated with substrates and 2-mercaptoethanol before adding glutamate

5. Incubated with 2-mercaptoethanol before adding substrates and glutamate

6. Incubated with 2-mercaptoethanol and EDTA before adding substrates and glutamate

$\begin{array}{cc}\text { Activity } & \begin{array}{c}\text { Percentage of } \\ \text { control activit }\end{array} \\ 7.05 & 100 \\ 1.45 & 21 \\ 4.05 & 58 \\ 2.42 & 34 \\ 0.97 & 14 \\ 4.11 & 59\end{array}$

reactivation on the addition of substrates, even although it resulted in an electrophoretic pattern which showed only the band characteristic of the native enzyme. Thus, 2-mercaptoethanol could bring about reassociation to form the dodecamer, but alone it did not reactivate the enzyme. Addition of EDTA together with 2-mercaptoethanol (Table 3) prevented the further loss of activity which occurred in the absence of substrates and, in this case, reactivation could be brought about by the subsequent addition of substrates. Addition of EDTA alone did not bring about reactivation of the enzyme or alter the electrophoretic pattern. Also, the addition of substrates alone did not alter the electrophoretic pattern. Prolonged dialysis (more than $24 \mathrm{~h}$ ) of the enzyme against buffer A caused irreversible inactivation of the enzyme and the appearance of at least six bands on gel electrophoresis. 


\section{DISCUSSION}

The success of the procedure detailed here for purifying glutamine synthetase to homogeneity depended on $\mathrm{Mg}^{2+}$, glutamate, EDTA and 2-mercaptoethanol being present throughout the purification. The biosynthetic activities of the purified enzymes were slightly higher than that of the enzyme from Anabaena CA (Stacey et al., 1977) but were much lower than those of the enzymes purified from heterotrophic prokaryotes (Woolfolk et al., 1966; Deuel et al., 1970; Wedler \& Hoffmann, 1974). The transferase activities of the purified enzymes were lower than that of the Anabaena CA enzyme, though this might be due to different assay conditions.

The molecular weight of glutamine synthetase from $A$. cylindrica was estimated to be 591000 by sedimentation analysis, the most satisfactory method of assay, and, like the Nostoc sp. enzyme, it was composed of 12 identical sub-units of 49000 to 50000 molecular weight, arranged in two superimposed hexagonal rings. The two cyanobacterial enzymes thus resembled the enzyme from other prokaryotes, e.g. Escherichia coli (Valentine et al., 1968; Ginsburg \& Stadtman, 1973), Bacillus subtilis (Deuel et al., 1970), Bacillus stearothermophilus (Wedler \& Hoffmann, 1974) and Anabaena CA, all of which have molecular weights of approximately 600000 and are composed of 12 identical sub-units, each of about 50000 molecular weight. They differed from the enzymes from various eukaryotes, e.g. Pisum sativum (O'Neal \& Joy, 1973), Candida utilis (Sims et al., 1974a), the cytosol of soya-bean root nodules (McParland et al., 1976) and of Lemna minor (Rhodes et al., 1978), which have molecular weights of 330000 to 390000 and eight sub-units each of about 45000 molecular weight arranged in two sets of planar tetramers (McParland et al., 1976).

Glutamine synthetase may be regulated by adenylylation-deadenylylation as in Gramnegative bacteria (Tronick et al., 1973), by feedback inhibition as in both prokaryotes and eukaryotes (see Prusiner \& Stadtman, 1973), by end-product inhibition by glutamine as in Bacillus subtilis (Deuel \& Stadtman, 1970), by a ligand-induced conformational change followed by dissociation as in Candida utilis (Sims et al., 1974a, b) and by a ligandinduced conformational change resulting in reversible enzyme deactivation as in Lemna minor (Rhodes et al., 1978). In agreement with our previous findings (Dharmawardene et al., 1973; Stewart et al., 1975; Rowell et al., 1977) we have been unable to demonstrate adenylylation-deadenylylation (Ginsburg \& Stadtman, 1973) of either cyanobacterial enzyme, even after adding cetyltrimethylammonium bromide to the cells, a technique which stabilizes the adenylylation state of the Rhodopseudomonas capsulata enzyme (Johansson \& Gest, 1977). However, we have observed a reversible deactivation of $A$. cylindrica glutamine synthetase which resembles in some respects what has been found with the enzymes of the eukaryotes Candida utilis (Sims et al., 1974a, b) and Lemna minor (Stewart \& Rhodes, 1977; Rhodes et al., 1978). For example, the requirements of the A. cylindrica enzyme for stabilization $\left(\mathrm{Mg}^{2+}\right.$, glutamate, EDTA and 2-mercaptoethanol) and for reactivation (2-mercaptoethanol and substrates of the biosynthetic reaction) were similar to those reported by Rhodes et al. (1978) for in vitro deactivated Lemna minor glutamine synthetase $\left(\mathrm{Mg}^{2+}\right.$, glutamate, ATP and a thiol reagent). Furthermore, the deactivation of purified $A$. cylindrica enzyme and the accompanying appearance of three bands on gels, one of which was possibly a half molecule and another a dimer or trimer (see Fig. 5a) suggests that dissociation proceeded via a rigid pattern, as with the Candida utilis enzyme (Sims et al., $1974 a, b)$. Such a mechanism has not hitherto been reported for a $\mathrm{N}_{2}$-fixing organism.

The reasons why the maximum reactivation of the enzyme observed was only $59 \%$ of that prior to deactivation are uncertain but the conditions which we used to reactivate the enzyme in vitro might have been sub-optimal. It is not possible, at present, to say whether the recovery in activity noted was due to reassociation of the dissociated forms of the enzyme, or whether it was simply dependent upon conformational changes in the dodecameric form of the enzyme (see Fig. 5). 
The reversible deactivation of glutamine synthetase from $A$. cylindrica might represent an example of a hysteretic enzyme (Frieden, 1970) which shows a slow response (relative to the catalytic reaction) to rapid changes in ligand concentration. Although caution must be exercised in extrapolating in vitro data to the situation in vivo, we have evidence, which will be presented elsewhere, that the $A$. cylindrica enzyme can be deactivated and reactivated in vivo and that the enzyme deactivated in vivo can be reactivated in vitro as described here. We have been unable to obtain evidence for a reversible deactivation of the purified enzyme from Nostoc sp.: this suggests that there may be some diversity in the mechanisms of regulation of glutamine synthetase in different cyanobacteria.

This work was supported by the Science Research Council and the Brazilian Agricultural Research Corporation. We thank Dr P. Cohen, Department of Biochemistry, University of Dundee, for carrying out the ultracentrifugation and for supplying fatty acid synthetase and phosphorylase kinase. We also thank Gail Alexander and Margaret Laing for technical assistance.

\section{REFERENCES}

Allen, M. B. \& ARnon, D. I. (1955). Studies on nitrogen-fixing blue-green algae. I. Growth and nitrogen fixation by Anabaena cylindrica Lemm. Plant Physiology 30, 366-372.

Brown, C. M. \& Herbert, R. A. (1977a). Ammonia assimilation in purple and green sulphur bacteria. FEMS Microbiology Letters 1, 39-42.

Brown, C. M. \& Herbert, R. A. (1977b). Ammonia assimilation in members of the Rhodospirillaceae. FEMS Microbiology Letters 1, 43-46.

Brown, C. M., Macdonald-Brown, D.S. \& Meers, J.L. (1974). Physiological aspects of microbial inorganic nitrogen metabolism. $A d$ vances in Microbial Physiology 11, 1-52.

DAvis, B. J. (1964). Disc electrophoresis. II. Method and application to human serum proteins. Annals of the New York Academy of Sciences 121, 404-427.

Deuel, T. F. \& Stadtman, E. R. (1970). Some kinetic properties of Bacillus subtilis glutamine synthetase. Journal of Biological Chemistry 245, 5206-5213.

Deuel, T. F., Ginsburg, A., Yeh, J., Shelton, E. \& Stadtman, E. R. (1970). Bacillus subtilis glutamine synthetase. Purification and physical characterisation. Journal of Biological Chemistry 245, 5195-5205.

Dharmawardene, M. W. N., Haystead, A. \& Stewart, W. D. P. (1973). Glutamine synthetase of the nitrogen-fixing alga Anabaena cylindrica. Archiv für Mikrobiologie 90, 281-295.

FrIEDEN, C. (1970). Kinetic aspects of regulation of metabolic processes: the hysteretic enzyme concept. Journal of Biological Chemistry 245, 57885799.

Ginsburg, A. \& Stadtman, E. R. (1973). Regulation of glutamine synthetase in Escherichia coli. In The Enzymes of Glutamine Metabolism, pp. 943. Edited by S. Prusiner \& E. R. Stadtman. New York and London: Academic Press.

Hedrick, J. L. \& Smith, A. J. (1968). Size and charge isomer separation and estimation of molecular weights of proteins by disc gel electrophoresis. Archives of Biochemistry and Biophysics 126, 155-164.
JoHANsson, B. C. \& Gest, H. (1977). Adenylylation/ deadenylylation control of the glutamine synthetase of Rhodopseudomonas capsulata. European Journal of Biochemistry 81, 365-371.

Kingdon, H. S., Hubbard, J. \& Stadtman, E. R. (1968). Regulation of glutamine synthetase. XI. The nature and implications of a lag phase in the $E$. coli glutamine synthetase reaction. Biochemistry 7, 2136-2142.

Ladha, J. K., Rowell, P. \& Stewart, W. D. P. (1978). Effects of 5'-hydroxylysine on acetylene reduction and $\mathrm{NH}_{4}{ }^{+}$assimilation in the cyanobacterium Anabaena cylindrica. Biochemical and Biophysical Research Communications 83, 688696.

LAYNE, E. (1957). Spectrophotometric and turbidometric methods for measuring proteins. Methods in Enzymology 3, 447-454.

Lowry, O. H., Rosebrough, N. J., Farr, A. L. \& Randall, R. J. (1951). Protein measurement with Folin phenol reagent. Journal of Biological Chemistry 193, 265-275.

McParland, R. H., Guevara, J. G., Becker, R. R. \& Evans, H. J. (1976). The purification and properties of the glutamine synthetase from the cytosol of soya-bean root nodules. Biochemical Journal 153, 597-606.

Meeks, J. C., Wolk, C. P., Thomas, J., Lockau, W., Shaffer, P. W., Austin, S. M., Chien, W.-S. \& Galonsky, A. (1977). The pathways of assimilation of ${ }^{13} \mathrm{NH}_{4}{ }^{+}$by the cyanobacterium Anabaena cylindrica. Journal of Biological Chemistry 252, 7894-7900.

MOORE, S. (1963). On the determination of cystine as cysteic acid. Journal of Biological Chemistry 238, 235- 237.

Nagatani, H., Shimizu, M. \& Valentine, R. C. (1971). The mechanism of ammonia assimilation in nitrogen-fixing bacteria. Archiv für Mikrobiologie 79, 164-175.

O'NeAL, D. \& JoY, K. W. (1973). Glutamine synthetase of pea leaves. I. Purification, stabilisation and $\mathrm{pH}$ optima. Archives of Biochemistry and Biophysics 159, 113-122. 
OWNBY, J. D. (1977). Effects of amino acids on methionine-sulphoximine-induced heterocyst formation in Anabaena. Planta 136, 277-279.

Pamiljans, V., Krishnaswamy, P. R., Dumville, G. \& Meister, A. (1962). Studies on the mechanism of glutamine synthetase: isolation and properties of the enzyme from sheep brain. Biochemistry 1, 153-158.

Prusiner, S. \& Stadtman, E. R., (editors) (1973). The Enzymes of Glutamine Metabolism. New York and London: Academic Press.

Rao, V. R., Darrow, R. A. \& Keister, D. L، (1978). Effect of oxygen tension on nitrogenase and on glutamine synthetases I and II in Rhizobium japonicum 61A76. Biochemical and Biophysical Research Communications 81, 224-231.

Rhodes, D., Sims, A. P. \& Stewart, G. R. (1978). Glutamine synthetase and the control of nitrogen assimilation in Lemna minor L. In Nitrogen Assimilation of Plants (in the Press). Edited by E. J. Hewitt \& C. V. Cutting. New York and London: Academic Press.

Rowell, P., Enticott, S. \& Stewart, W. D. P. (1977). Glutamine synthetase and nitrogenase activity in the blue-green alga Anabaena cylindrica. New Phytologist 79, 41-54.

Sawhney, S. K. \& Nicholas, D. J. D. (1978). Some properties of glutamine synthetase from Anabaena cylindrica. Planta 139, 289-299.

SCHACHMAN, H. K. (1957). Ultracentrifugation, diffusion and viscometry. Methods in Enzymology 4, 32-103.

Sims, A. P., Toone, J. \& Box, V. (1974a). The regulation of glutamine synthesis in the food yeast Candida utilis: the purification and subunit structure of glutamine synthetase and aspects of enzyme deactivation. Journal of General Microbiology 80, 485-489.

Sims, A. P., Toone, J. \& Box, V. (1974b). The regulation of glutamine metabolism in Candida utilis: mechanisms of control of glutamine synthetase. Journal of General Microbiology 84, 149162.

Spackman, D. H., Stein, W. H. \& Moore, S. (1958). Automatic recording apparatus for use in the chromatography of amino acids. Analytical Chemistry 30, 1190-1206.

Spies, J. R. \& Chambers, D. C. (1949). Chemical determination of tryptophan in proteins. Analytical Chemistry 21, 1249-1266.

Stacey, G., Tabita, F. R. \& Van BaAlen, C. (1977). Nitrogen and ammonia assimilation in the cyanobacteria: purification of glutamine synthetase from Anabaena sp. strain CA. Journal of Bacteriology 132, 596-603.

Stanier, R. Y., Kunisawa, R., Mandel, M. \& Cohen-Bazire, G. (1971). Purification and pro- perties of unicellular blue-green algae (order Chroococcales). Bacteriological Reviews 35, 171205.

Stewart, G. R. \& Rhodes, D. (1977). Control of enzyme levels in the regulation of nitrogen assimilation. In Regulation of Enzyme Synthesis and Activity, pp. 1-22. Edited by H. Smith. London: Academic Press.

STEWART, W. D. P. \& Rowell, P. (1975). Effects of L-methionine-DL-sulphoximine on the assimilation of newly fixed $\mathrm{NH}_{3}$, acetylene reduction and heterocyst production in Anabaena cylindrica. Biochemical and Biophysical Research Communications 65, 846-856.

Stewart, W. D. P., Haystead, A. \& DharmawarDENE, M. W. N. (1975). Nitrogen assimilation and metabolism in blue-green algae. In Nitrogen Fixation by Free-Living Micro-organisms, I.B.P. vol. 6, pp. 129-158. Edited by W. D. P. Stewart. Cambridge: Cambridge University Press.

Thomas, J., Meeks, J. C., Wolk, C. P., Shaffer, P. W., Austin, S. M. \& Chien, W.-S. (1977). Formation of glutamine from $\left[{ }^{13} \mathrm{~N}\right]$ ammonia, $\left[{ }^{13} \mathrm{~N}\right]$ dinitrogen, and $\left[{ }^{14} \mathrm{C}\right]$ glutamate by heterocysts isolated from Anabaena cylindrica. Journal of Bacteriology 129, 1545-1555.

Tronick, S. R., Ciardi, J. E. \& Stadtman, E. R. (1973). Comparative biochemical and immunological studies of bacterial glutamine synthetases. Journal of Bacteriology 115, 858-868.

V.alentine, R. C., Shapiro, B. M. \& Stadtman, E. R. (1968). Regulation of glutamine synthetase. XII. Electron microscopy of the enzyme from Escherichia coli. Biochemistry 7, 2143-2152.

WeBer, K. \& OsBorn, M. (1969). The reliability of molecular weight determinations by dodecyl sulphate-polyacrylamide gel electrophoresis. Journal of Biological Chemistry 244, 4406-4412.

Wedler, F. C. \& Hoffmann, F. M. (1974). Glutamine synthetase of Bacillus stearothermophilus. I. Purification and basic properties. Biochemistry 13, 3207-3214.

Wolk, C. P., Thomas, J., Shaffer, P. W., Austin, S. M. \& GAlonsKy, A. (1976). Pathway of nitrogen metabolism after fixation of ${ }^{13} \mathrm{~N}$-labelled nitrogen gas by the cyanobacterium, Anabaena cylindrica. Journal of Biological Chemistry 251, 5027-5034.

Woolfolk, C. A., Shapiro, B. \& Stadtman, E. R. (1966). Regulation of glutamine synthetase. I. Purification and properties of glutamine synthetase from Escherichia coli. Archives of Biochemistry and Biophysics 116, 177-192.

Yphantis, D. A. (1964). Equilibrium ultracentrifugation of dilute solution. Biochemistry 3, 297317. 